\section{Audiology \\ Neurotology}

Audiol Neurotol 2006;11:342

DOI: $10.1159 / 000095895$
Published online: September 21, 2006

\title{
In Memoriam Manfried Hoke
}

Professor Manfried Hoke's history with Karger Publishers and the journal Audiology \& Neurotology began 11 years ago.

In 1995, Karger had already been publishing an audiology journal with the International Society of Audiology for 24 years. When the society decided to change publishers, taking the journal with them, Karger was reluctant to abandon the work of so many years in the field of audiology and found a willing and dedicated partner in Professor Hoke. Thus, a new journal, then spelt Audiology \& Neuro-Otology, was born, and a personal friendship developed with its Editor-in-Chief.

For 10 years Professor Hoke worked with us as Editorin-Chief, promoting the journal with untiring effort and dedication, and leading it to the highest rank in its field. Thanks to him Audiology \& Neuro-Otology came top of the otolaryngology journals for four consecutive years (1999-2002) in the Institute for Scientific Information's Science Citation Index, its highest Impact Factor being 2.532. Professor Hoke was ably assisted by his wife, Ellen Hoke, who served as the journal's Managing Editor through the years of his tenure. We look back with plea- sure to our many meetings at congresses around the world, at Professor Hoke's offices in Münster and at Karger headquarters in Basel, where he would often stop over on his travels. Our conversations ranged far beyond mere business discussions, and we learned much from each other over the years.

In 2004 Professor Hoke's failing health obliged him to step down from his post as Editor-in-Chief, and during an interim period Audiology \& Neuro-Otology was managed by Associate Editor Professor B. Lütkenhöner, Münster. We are very grateful to him for being willing to step into the gap so spontaneously. The journal then passed into the capable hands of Professor J. Harris, San Diego, who is admirably continuing the work Manfried Hoke began.

We much regret the passing of Professor Hoke and extend our most sincere condolences to his wife, Ellen Hoke. Our memories of him are and will remain those of a great collaborator and friend.

Thomas Karger Steven Karger

\begin{tabular}{ll}
\hline KARGER & ( 2006 S. Karger AG, Basel \\
Fax +4161306 12 34 & \\
$\begin{array}{l}\text { E-Mail karger@karger.ch } \\
\text { www.karger.com }\end{array}$ & $\begin{array}{l}\text { Accessible online at: } \\
\text { www.karger.com/aud }\end{array}$
\end{tabular}

